\title{
A Study of the Correlation of Some Sex Hormone with Obesity in Women with Secondary Infertility
}

\author{
Alaa H. Jawad*, Suhad A. Ibrahim*, Zyad H. Jawad** and Donya M. Hadi* \\ * Department of Chemistry, College of Science, Al-Nahrain University, Baghdad-Iraq. \\ ** Department of Chemistry, College of Science, Al-Mustansirya, Baghdad-Iraq.
}

\begin{abstract}
Infertility is the inability to conceive a child for more than one year. The present study indicates that the obesity associated with infertility. The aim of the study to determine follicle stimulating hormone, luteinizing hormone, testosterone hormone and prolactin levels. and cholesterol and triglyceride concentration in $2^{\text {nd }}$ inferetid women. This study was carried out at kamal al-samaarai hospital the data were collected from 95 secondary infertilial women were age between 16-45 years old and grouped them in to obese $(n=47)$ and non obese $(n=49)$. There was no significant difference between the two groups ( $p>0.05)$. Body mass index in Infertile obese women is slightly higher than non obese Infertile women which is statistically significant $(\mathrm{P}<0.001)$. However LH, $\mathrm{TSH}$, cholesterol and triglyceride concentration in obese infertile women is significantly higher than non obese infertile women $(\mathrm{p}<0.05)$. The BMI was correlated positively with triglyceride in obese group while BMI was positive correlation highly significant with cholesterol in non obese group. Regression analysis revealed obese to be strongly associated with observed infertility. The elevated prolactin values in secondary infertile women clearly shows that there is a mechanism operating at the anterior pituitary level which shows an abnormal distribution of FSH and LH which may further explain the abnormal delay ovum maturation. This study also indicates obese associated with infertile more than non obese women.
\end{abstract}

Keywords: Infertility, hormones Follicle stimulating hormone, Luteinizing hormone, Thyroid stimulating hormone.

\section{Introduction}

Infertility is the inability to conceive a child for more than one year. It has two types: Primary infertility is infertility in which a woman has never had a child. Secondary infertility is infertility in which a woman is unable to bear a child, either due to the inability to become pregnant or the inability to carry a pregnancy to a live birth following either a previous pregnancy or a previous ability to carry a pregnancy to a live birth [1]. Infertility has increased by 4 percent since the 1980s, mostly from problems with fecundity due to an increase in age women can also increase risk of miscarriages and failure the outcomes of assisted reproductive technologies and pregnancy.

Infertility may be caused by an underlying medical condition that maydamage the fallopian tubes, interferes with ovulation, or causes hormonal complications. Also Triglycerides change dramatically in response to meals, increasing as much as 5 to 10 times higher than fasting levels just a few hours after eating. Even fasting levels vary considerably day to day. Therefore, modest changes in fasting triglycerides measured on different days are not considered to be abnormal. These medical conditions include. About 40 percent of the issues involved with infertility are due to the man, another 40 percent due to the woman, and 20 percent result from complications with both partners [2]. Most cases of female infertility are caused by problems with ovulation. Without ovulation, there are no eggs to be fertilized. Some signs that a woman is not ovulating normally include irregular or absent menstrual periods. The infertility causes due to insufficiency or imbalance hormones, deficiencies in luteinizing hormone ( $\mathrm{LH})$, follicle stimulating hormone $(\mathrm{FSH})$ and elevated prolactin level even slight irregularities in the hormone system can affect ovulation [3]. Ovulation problems are often caused by polycystic ovarian syndrome (PCOS) in which the eggs only partially developed within the ovary and there are male hormones excess. Some women are infertile because their ovaries do not mature and release egg. Primary ovarian 
insufficiency is another cause of ovulation problems. It is occurs when a woman's ovaries stop working normally before she is 40s. Less common causes of fertility problems in women include the blockage of the Fallopian tube due to malformations, infections such as chlamydia and/or scar tissue [4], or physical problems with the uterus. There are other factors that can affect awoman's chances of conceiving include being overweight or underweight, or her age as female fertility declines after the age of 35 . Sometimes it can be a combination of factors, and sometimes a clear cause is never established. Ovarian dysfunction could be caused by weight loss and excessive weight gain with body mass index (BMI) greater than $27 \mathrm{~kg} / \mathrm{m}^{2}$ [5]. Excess weight has also been found to have effect on treatment efficacy and outcomes of assisted reproductive technique [6]. Estrogen is produced by pelvic inflammatory disease, endometriosis, polycystic ovarian syndrome, premature ovarian failure, uterine fibroids and environmental factors [5]. The aim of the study was to compares between obese and non obese secondary infertile women by estimate the levels of serum follicle stimulating hormone, luteinizing hormone prolactin and TSH levels cholesterol and triglyceride concern also included in this study with BMI and to investigate the correlation between all parameters in this study.

\section{Materials and Methods \\ Subjects}

The present investigation was carried out at kamal al-samaarai in Iraq, the data were collected from 95 women with secondary infertility their age rang (16-45) years and grouped into obese $(n=46)$ and non obese $(n=49)$.

\section{Sampling}

The blood was collected during mid cycle (14-16) day on fasting by venipuncture. The blood was allowed to clot, then serum was collected for analysis. The serum was stored at $(-20) C^{\circ}$.

\section{Clinical investigation}

The physical examination of body weight was calculated by taking weight in kilogram $(\mathrm{kg})$, and height was measured in centimeters
[9]. Age, height, weight, BMI The Body Mass index was calculated from the formula; BMI = weight (kilograms) $/$ height $\left(\mathrm{m}^{2}\right)$, $\mathrm{FSH}, \mathrm{LH}$, testosterone, TSH were estimated by immuno enzymatic assay by mini VIDAS reader, cholesterol and triglyceride were estimated by using kit method (Biomerieux,ITV12I5696 -france).

\section{Statistical Analysis}

The significance of difference between the groups was tested using the student t-test analysis, and the results of hormones (FSH, LH, Testosterone, TSH) cholesterol and triglyceride, were expressed as mean \pm SD and correlation between parameters had been examined by using Microsoft excel and Statistical Package for the Social Sciences (SPSS) Software 14.0 version.

The fat cells and primary sex organs and thus, state of high body fat or obesity causes increase in estrogen production which the body interprets as birth control, limiting the chances of getting pregnant also, too little body fat causes insufficient estrogen production and thus menstrual irregularities with an ovulatory cycle [7]. Proper nutrition in early life had been linked to be a major factor for later fertility [8]. Fertility can be negatively affected by obesity. In women, early onset of obesity favors the development of menstrual irregularities, Obesity in.

\section{Results and Discussion}

Average values of anthropometric parameters: body mass index (BMI), age, height and weight, of infertile obese groups and non obese infertile groups are shown in Table -1. Body mass index in Infertile obese women was higher than non obese infertile women which is statistically significant $(\mathrm{P}<0.001)$. FSH, prolactin, testosterone hormones in infertile obese women showed no significant difference $(\mathrm{p}>0.05)$. However LH, $\mathrm{TSH}$, cholesterol and triglyceride evels in obese infertile women was signific antly higher than non obese infertile women $(\mathrm{p}<0.05)$. 
Table (1)

Anthropometric Parameters of Obese and Non Obese Infertile Groups.

\begin{tabular}{||l||c|c|c|}
\hline \multicolumn{1}{|c|}{ Parameters } & $\begin{array}{c}\text { obese group } \\
\boldsymbol{n}=\mathbf{4 6} \\
\text { Mean } \pm \text { SD }\end{array}$ & $\begin{array}{c}\text { Non obese group } \\
\boldsymbol{n = 4 9} \\
\text { Mean } \pm \text { SD }\end{array}$ & p-value \\
\hline \hline Age $($ year) & $32.308 \pm 7.031$ & $26.800 \pm 6.843$ & $0.023^{*}$ \\
\hline Height $(\mathbf{c m})$ & $158.692 \pm 5.156$ & $159.520 \pm 7.366$ & 0.704 \\
\hline Weight $(\mathbf{k g})$ & $76.744 \pm 9.324$ & $58.040 \pm 6.548$ & $0.00^{* *}$ \\
\hline BMI $\left(\mathbf{k g ~} / \mathbf{m}^{2}\right)$ & $30.359 \pm 3.543$ & $22.712 \pm 1.714$ & $0.00^{* *}$ \\
\hline
\end{tabular}

Table (2)

P-value for Hormonal and the Lipids Study.

\begin{tabular}{|l||c|c|c||}
\hline \multicolumn{1}{|c|}{ Parameters } & $\begin{array}{c}\text { obese group } \\
n=46 \\
\text { Mean } \pm \text { SD }\end{array}$ & $\begin{array}{c}\text { Non obese group } \\
n=49 \\
\text { Mean } \pm \text { SD }\end{array}$ & p-value \\
\hline FSH (Units/L ) & $6.715 \pm 3.022$ & $6.524 \pm 2.505$ & 0.334 \\
\hline LH (Units/L ) & $2.542 \pm 1.477$ & $3.584 \pm 1.991$ & $0.028^{*}$ \\
\hline Prolactin(ng/mL) & $25.810 \pm 14.111$ & $24.296 \pm 17.310$ & 0.986 \\
\hline Testosterone (ng/mL) & $0.316 \pm 0.155$ & $0.259 \pm 0.169$ & 0.164 \\
\hline TSH (mIU/L) & $2.314 \pm 1.759$ & $2.786 \pm 1.603$ & $0.027^{*}$ \\
\hline Cholesterol $(\mathbf{m g} / \mathbf{d l})$ & $5.462 \pm 0.990$ & $4.552 \pm 0.789$ & $0.002^{*}$ \\
\hline Triglyceride(mg/dl) & $138.926 \pm 2.018$ & $106.208 \pm 32.915$ & $0.007^{*}$ \\
\hline
\end{tabular}

Values are mean \pm SD (Standard Deviation), $* \mathbf{P}<0.05$, ** $\mathbf{P}<0.001$

Many other studies have proved significant deviation in $\mathrm{FSH}, \mathrm{LH}$ and testosterone levels in obese infertile women [10]. Body fat plays a critical role in human reproduction. Both excess and deficiency of body fat lead To reproductive failure. A body weight disorders is one of the first potential causes of reproductive failure in both men and women [11]. This is a problem that can be corrected by the affected individual and the infertile couple.

Table (3)

Showing correlation for obese infertile women.

\begin{tabular}{|c|c|c|c|c|c|c|c|c|c|}
\hline & & weight & $B M I$ & $F S H$ & $L H$ & Prolactin & Testosterone & $T S H$ & Cholesterol \\
\hline \multirow[t]{2}{*}{ Weight } & $\mathrm{R}$ & & & & & & & & \\
\hline & P-value & & & & & & & & \\
\hline \multirow[t]{2}{*}{ BMI } & $\overline{\mathrm{R}}$ & $\frac{1.821^{* *}}{}$ & & & & & & & \\
\hline & P-value & (.000 & & & & & & & \\
\hline \multirow[t]{2}{*}{$\overline{\text { FSH }}$} & $\mathrm{R}$ & -.267 & -.255 & & & & & & \\
\hline & P-value & .100 & .118 & & & & & & \\
\hline \multirow[t]{2}{*}{ LH } & $\mathrm{R}$ & -.140 & -.220 & $\begin{array}{l}-.011 \\
\end{array}$ & & & & & \\
\hline & P-value & .396 & .179 & 9.948 & & & & & \\
\hline \multirow[t]{2}{*}{ Prolactin } & $\overline{\mathrm{R}}$ & -..135 & $\begin{array}{l}-.154 \\
\end{array}$ & $\begin{array}{l}-.129 \\
\end{array}$ & 1.181 & & & & \\
\hline & P-value & .411 & .348 & .435 & 2.269 & & & & \\
\hline \multirow[t]{2}{*}{ Testosterone } & $\mathrm{R}$ & .039 & -.037 & -.231 & .167 & -.069 & & & \\
\hline & P-value & .813 & .821 & .157 & .310 & .679 & & & \\
\hline \multirow[t]{2}{*}{ TSH } & $\mathrm{R}$ & -.101 & -.164 & $.343^{*}$ & -.178 & .091 & -.113 & & \\
\hline & P-value & 2.539 & .319 & .033 & .278 & 2.583 & .492 & & \\
\hline \multirow[t]{2}{*}{ Cholesterol } & $\bar{R}$ & $\begin{array}{l}.013 \\
.013\end{array}$ & 167 & 169 & $\begin{array}{l}-.037 \\
\end{array}$ & -.231 & 166 & 177 & \\
\hline & P-value & .938 & .310 & . .304 & .822 & .156 & .312 & .281 & \\
\hline \multirow[t]{2}{*}{ Triglyceride } & $\mathrm{R}$ & .267 & $.415^{* *}$ & .032 & .306 & -.147 & .132 & .073 & .224 \\
\hline & P-value & .100 & .009 & .845 & .059 & .373 & .425 & .658 & .170 \\
\hline
\end{tabular}

*. Correlation is significant at the 0.05 level (2-tailed).

**. Correlation is significant at the 0.01 level (2-tailed). 
As shown in Table (3), there were no significant correlation between the parameters except that of the positive correlation between TSH and FSH in obese women. Table (4) showed significant negative correlation between TSH and weight. TSH correlated positively with cholesterol and triglyceride in non obese women. No correlation were found between other parameters. According to Emokpae MA., there may be failure at the hypothalamus or pituitary (hypogonadotropic hypogonadism) which result in decreased serum FSH \& LH with increase in serum Prolactin levels that leads to infertility [11]. Emokpae MA, suggest that increased in serum prolactin result in amenorrhea because of defect in the positive feedback of estrogen on $\mathrm{LH}$, an lead to decreased in serum $\mathrm{LH}$ values [12] which was in line with our study. Our study coincide with study of K. Mohan \& Mazher Sultana and suggested that decreased level of LH in the midcycle clearly indicates that there is a possibility of an ovulation [9]. More than $70 \%$ of women who are infertile as the result of body weight disorders will conceive spontaneously if their weight disorder is corrected through a weight-gaining or weight-reduction diet as appropriate.

Table (4)

Showing correlation for non obese infertile women.

\begin{tabular}{|c|c|c|c|c|c|c|c|c|c|}
\hline & & Weight & BMI & FSH & $\overline{L H}$ & Prolactin & testosterone & $T S H$ & Cholesterol \\
\hline \multirow[t]{2}{*}{ Weight } & $\mathrm{R}$ & & & & & & & & \\
\hline & P-value & & & & & & & & \\
\hline \multirow[t]{2}{*}{ BMI } & $\mathrm{R}$ & $.575^{* *}$ & & & & & & & \\
\hline & P-value & .003 & & & & & & & \\
\hline \multirow[t]{2}{*}{ FSH } & $\mathrm{R}$ & -.241 & .037 & & & & & & \\
\hline & P-value & .246 & .861 & & & & & & \\
\hline \multirow[t]{2}{*}{$\mathbf{L H}$} & $\mathrm{R}$ & -.079 & -.240 & -.043 & & & & & \\
\hline & P-value & .708 & .248 & .840 & & & & & \\
\hline \multirow[t]{2}{*}{ Prolactin } & $\mathrm{R}$ & -.149 & .179 & .085 & .056 & & & & \\
\hline & P-value & .478 & .391 & (.687 & (790 & & & & \\
\hline \multirow[t]{2}{*}{ Testosterone } & $\mathrm{R}$ & -.188 & -.254 & -.147 & .050 & -.015 & & & \\
\hline & P-value & .368 & .221 & .482 & .811 & .944 & & & \\
\hline \multirow[t]{2}{*}{ TSH } & $\mathrm{R}$ & $-.398^{*}$ & -.088 & .322 & -.094 & -.036 & -.281 & & \\
\hline & P-value & .049 & .676 & .116 & .654 & .863 & .174 & & \\
\hline \multirow[t]{2}{*}{ "Cholesterol } & $\mathrm{R}$ & .058 & $.409^{*}$ & .320 & -.252 & .012 & -.244 & $.591^{* *}$ & \\
\hline & P-value & .784 & .042 & .118 & .225 & .953 & .239 & .002 & \\
\hline \multirow[t]{2}{*}{ Triglyceride } & $\mathrm{R}$ & -.358 & -.280 & .236 & -.028 & -.032 & -.160 & $.484^{*}$ & $.459^{*}$ \\
\hline & P-value & .079 & .175 & .256 & .894 & .880 & .444 & .014 & .021 \\
\hline
\end{tabular}

\section{*. Correlation is significant at the 0.05 level (2-tailed).}

**. Correlation is significant at the 0.01 level (2-tailed).

Obese women experience first a change in their reproductive cycles. Their cycles become irregular, unpredictable and often heavy and prolonged. Heavy, prolonged cycles correlate with increased estrogen production in the forms of estrone and estriol. In addition, obese women will often notice the appearance of dark (terminal) hair on the lower abdomen, face and between the breasts. This terminal hair results from the increased ovarian production of androstenedione that occurs with obesity. The initial sign of altered anovulation. Women with hormonal imbalance will not produce enough follicles to ensure the development of an ovule [15]. Yet, body weight is often considered last in an infertility evaluation, the body weight of both partners of the infertile couple should be considered first when there is an obvious slender or obese body form in either partner. Also, awareness of the importance of body weight on reproduction enables couples to maintain appropriate body weight or to correct a body weight disorder before subjecting themselves to expensive, time consuming infertility evaluation and treatment reproductive cycles is similar to that of obese women. Obesity affects approximately half of the general population 
and is thus a common problem among the fertile population. Obese women have a higher prevalence of infertility compared with their lean counterparts. The majority of women with an ovulatory disorder contributing to their infertility have polycystic ovary syndrome (PCOS) and a significant proportion of women with PCOS are obese. Ovulation disorders and obesity-associated infertility represent a group of infertile couples that are relatively simple to treat. The incidence of hyperprolactinemia in women was found to be $62.16 \%$ (Rajan, et al., 1990) and 0\% (Avasthi kumkum, et al., 2002). The levels of FSH, LH and Prolactin onodotropic hormones in infertile women were evaluated by many researchers. According to Moltz, et al., (1991) higher level of FSH, LH in infertile women with a proper menstrual cycle is rarely found. However lower concentration of those hormones observed only in $8 \%$ of cases. Moltz et al, (1991) also states that $65.5 \%$ of infertile women with proper two-phase menstrual cycles suffered from luteal phase defects but in $28.7 \%$ of cases lower values of FSH and $\mathrm{LH}$ were noticed. [13]. Kohler (Givens et al, 1986) States that women with higher values of prolactin and luteal phase defects have lower levels of FSH, and LH during their menstrual cycle. Both luteinizing hormone (LH) and Follicle-stimulating hormone (FSH) are required for follicle development and estrogen production. Due to elevated of prolactin, the follicle-stimulating hormone and luteinizing hormone are decreased and causes infertility [9]. The obesity influences the reproductive cycle by impaired estrogen metabolism causing menstrual disturbance and an ovulation. The present study clearly indicates that all the obese patients increased in serum prolactin level and decreased FSH levels. The hypothalamus, through the release of gonadotrophin releasing hormones, controls the pituitary gland which directly or indirectly controls most other hormonal glands in the human body. Thus, alterations in the chemical signals from the hypothalamus can affect the pituitary gland, ovaries, thyroid, mammary gland and hence, hormonal abnormalities. Hormonal anomalies that affect ovulation include hyperthyroidism, hypothyroidism, polycystic ovary syndrome (also known as Stein-Leventhal syndrome) and hyperprolactinemia [14].

\section{Acknowledgment}

The authors thank Al-Nahrain University for funding and support.

\section{References}

[1] Zegers B and Heavy F; Management of Infertility within Primary Health Care Programming; Sudan, Asian J. of Scientific Research 4 (2):158-164, 2011.

[2] Anwer S, Shehnaz N, "Pitutary Gonadotropic Hormones In Women with Oligo Amenorrhoea". J. Ayub Medical College, 20: 345-355, 2008.

[3] Agboola A, Textbook of "Obstetrics and Gynaecology", Heinman Educational Books, Ibadan, 1: 174- 176, 2004.

[4] low. V. American Society for Reproductive Medicine, "Fertility sterility" J., 90: 45-58, 2008.

[5] Olooto B., Wasiu E., Amballi A., and Banjo, Taiwo A., A review of Female Infertility; important etiological factors and management": J. Microbiol. Biotech. Res, 2 (3): 379-385: 2012.

[6] Freundl G, Godehardt E, PA Kern, FrankHerrmann P., Koubenec J., "Hormones and behavior" Reprod, 18 (12): 2628-2633 : 2003.

[7] American Society for Reproductive Medicine," Fertility Female Risks,: 2009.

[8] Sloboda DM, Hickey M, Hart R." Human Reproduction," Update 17 (2): 210-227, 2010.

[9] Mohan K and Mazher S, "Follicle Stimulating Hormone, Luteinizing Hormone and Prolactin Levels in Infertile Women in North Chennai". J. Bio Sci Re. 1(4): 279-284 2010.

[10] Goswami B, Patel, S; Chatterjee, Mainak; K; Saxena, A, "Correlation of Prolactin and Thyroid Hormone Concentration with Menstrual Patterns in Infertile Women", 10(3): 207-12. 2009.

[11] Emokpae M. A. "Hormonal Evolutions and Endometrial Biopsy in Infertile Women in Kano, Northern Nigeria. Annals of African, Medicine, 4: 99-103, 2005. 
[12] Roczniki A, kademii M, Białymstok U, "Incidence of elevated LH/FSH ratio in polycystic ovary syndrome women with normo- and hyperinsulinemia, covary syndrome women with normo-and hyperinsuli. Annales Academia Medicae Bialostocensis",. 48. 2003.

[13] Sunita A, Turankar; "Study OF Serum Follicular Stimulating, Lutienising \& Prolactin hormonal levels in Primary Infertility"; Department of Biochemistry Grant Medical College, JJ groups of hospital Mumbai, 2011.

[14] Richard S.MD, Discussant, "old woman with a Diagnosis of polycystic ovary syndrome", JAMAS, 5: 43-55, 2007.

[15] Pigny P, Cortet- Rudelli C, Decanter C, Deroubaix D, Soudan B," Serum levels of inhibits are differentially altered in patients with polycystic ovary syndrome : effects of being overweight and relevance to hyperandrogenism". Fertil Steri, 3: 973978, 2000.

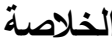

العقم هو عدم قدرة المرأة على انجاب طفل.تثير هذه

الدراسة الى علاقة السمنة المفرطة مع العقم لتحديد هرمون لهرهاب

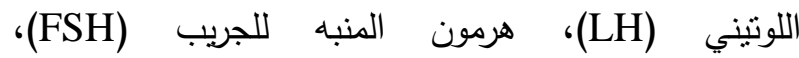
التيستستيرون والبرولاكتين ،وكذلك تركيز الكوليستيرول والدهون الثلاثية، اجريت هذه الدراسة في مستشفى كمال السامرائي، وقد تم جمع البيانات من 90 امراة بالعقم الثانوي وكانت اعمارهن نتراوح بين (7 ا-0 ؛ سنة وتم تقسيمهن الى لى

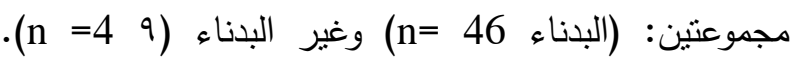
أظهرت النتائج عدم وجود اختلاف معنوي بين النساء البدينات وغير البدينات لهرمون المنبه للجريب (FSH)؛ التستيستيرون، والبرولاكتين في نساء البدينات. اللاتي يعانين

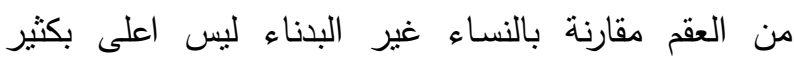

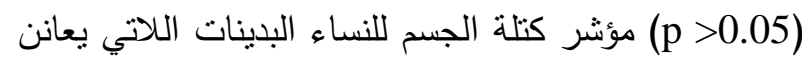
من العقم مقارنة بالنساء غير البدناء كانت اعلى بقلى بليل

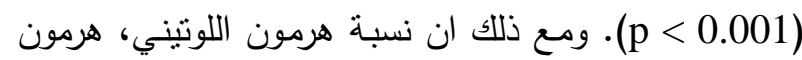

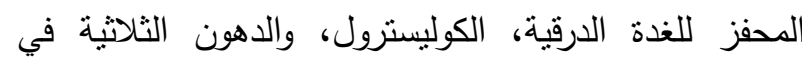
النساء البدينات اللاتي يعانن من العقم هي اعلى بكثير مما
كانت عليه في النساء الغير بدينات (p0.05 p p) أظهر مؤشر

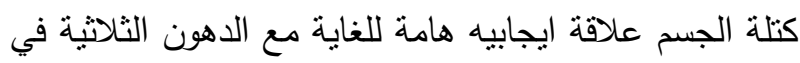
مجموعة البدناء في حين كان مؤشر كتلة الجسم علاقة ايجابية هامة للغاية دع الكوليستيرول في المجموعة غير هير البدناء. واظهرت لنا التحليلات بان السمنة المفرطة لها علاقة مباشرة مع العقم. قيم البرولاكتين المرتقعة لدى النساء المصابات بالعقم الثانوي يبين بوضوح ان هناك الية تعمل على مستوى الفصى الامامي لغدة النخامية التي يظهر لتهري

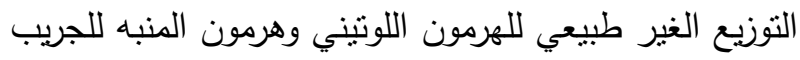
الذي قد يبين سبب تاخير نضوج البويضة. 